\title{
Phenotypic PIA-Dependent Biofilm Production by Clinical Non-Typeable Staphylococcus aureus Is Not Associated with the Intensity of Inflammation in Mammary Gland: A Pilot Study Using Mouse Mastitis Model
}

\author{
Jully Gogoi-Tiwari ${ }^{1,2, *}$, Dorji Dorji ${ }^{1,3}$, Harish Kumar Tiwari ${ }^{4}\left(\mathbb{D}\right.$, Gayatri Shirolkar ${ }^{1}$, Joshua W. Aleri ${ }^{2,5,+}$ \\ and Trilochan Mukkur 1,+
}

1 Curtin Health Innovation Research Institute, Curtin Medical School, Curtin University, Bentley, Perth, WA 6102, Australia; dorji1@graduate.curtin.edu.au (D.D.); gayatri.shirolkar@curtin.edu.au (G.S.); tk_mukkur@hotmail.com (T.M.)

2 School of Veterinary Medicine, College of Science, Health, Engineering and Education, Murdoch University, 90 South Street, Murdoch, WA 6150, Australia; J.Aleri@murdoch.edu.au

3 Department of Microbiology, Jigme Dorji Wangchuck National Referral Hospital, Khesar Gyalpo University of Medical Sciences, Thimphu 11001, Bhutan

check for

updates

Citation: Gogoi-Tiwari, J.;

Dorji, D.; Tiwari, H.K.; Shirolkar, G.;

Aleri, J.W.; Mukkur, T. Phenotypic

PIA-Dependent Biofilm Production

by Clinical Non-Typeable

Staphylococcus aureus Is Not

Associated with the Intensity of

Inflammation in Mammary Gland:

A Pilot Study Using Mouse Mastitis

Model. Animals 2021, 11, 3047.

https://doi.org/10.3390/ani11113047

Academic Editors:

Mahmoud M. Naguib,

Mrigendra Rajput

and Mehdi Soltani

Received: 26 August 2021

Accepted: 15 October 2021

Published: 25 October 2021

Publisher's Note: MDPI stays neutral with regard to jurisdictional claims in published maps and institutional affiliations.

Copyright: (C) 2021 by the authors. Licensee MDPI, Basel, Switzerland. This article is an open access article distributed under the terms and conditions of the Creative Commons Attribution (CC BY) license (https:/ / creativecommons.org/licenses/by/ $4.0 /)$.
4 Asia-Pacific Consortium of Veterinary Epidemiology, Sydney School of Veterinary Science, The University of Sydney, Camden, NSW 2570, Australia; harish.tiwari@sydney.edu.au

5 Centre for Animal Production and Health, Future Foods Institute, Murdoch University, 90 South Street, Murdoch, WA 6150, Australia

* Correspondence: Jully.Gogoitiwari@murdoch.edu.au

+ Equal senior authors.

Simple Summary: Staphylococcus aureus-associated human clinical infections are predominantly caused by the encapsulated strains, with non-typeable strains representing less than $25 \%$. In contrast, $80 \%$ of the S. aureus from bovine mastitis cases are non-typeable as they do not possess the Capsular Types 1, 2, 5, and 8. In our previous studies, it was demonstrated that the extent of mammary tissue damage was associated with the strength of biofilms formed by encapsulated $S$. aureus strains. This study assesses the impact of biofilm formation, as a virulence factor of non-typeable Staphylococcus aureus, causing mammary tissue damage in a mouse mastitis model. The study demonstrates no association between the strength of biofilm production by non-typeable $S$. aureus and the mammary tissue damage. However, the mice infected with strong biofilm producing non-typeable S. aureus died $6 \mathrm{~h}$ earlier than those infected with weak biofilm producing non-typeable $S$. aureus suggesting the role of biofilm in the advancement of the time of mice mortality.

Abstract: Non-typeable (NT) Staphylococcus aureus strains are associated with chronic bovine mastitis. This study investigates the impact of biofilm formation by clinical NT S. aureus on cytokine production and mammary tissue damage by using a mouse mastitis model. Mice infected with two different NT S. aureus strains with strong and weak biofilm forming potential demonstrated identical clinical symptoms (moderate), minimal inflammatory infiltrates, and tissue damage (level 1 histopathological changes) in the mammary glands. However, the S. aureus load in the mammary glands of mice and the level of pro-inflammatory cytokines (IL-1 $\beta$, IL-6, IL-12, IL-17 and IFN- $\gamma$ ) in serum were significantly higher $(p \leq 0.05)$ in those infected with the strong biofilm forming NT S. aureus strain. The level of IL-6 in sera samples of these mice was extremely high $(15,479.9 \pm 532 \mathrm{Pg} / \mathrm{mL})$. Furthermore, these mice died in $24 \mathrm{~h}$ of post infection compared to $30 \mathrm{~h}$ in the weak biofilm forming NT S. aureus infected group. The study demonstrates no association between the strength of PIA (polysaccharide intercellular adhesion)-dependent biofilm production by clinical NT S. aureus and mammary gland pathology in a mouse mastitis model. However, the role of biofilm in the virulence of $S$. aureus advancing the time of mortality in mice warrants further investigation. 
Keywords: Staphylococcus aureus; non-typeable; biofilm; tissue damage; inflammation; bovine mastitis; mouse model

\section{Introduction}

Presence of capsular polysaccharide $(\mathrm{CP})$ and the biofilm forming ability of $S$. aureus are the major virulence determinants of the pathogen [1,2]. Capsular polysaccharide helps the organism to evade phagocytosis allowing the pathogen to persist in tissues and blood stream of the infected host [3]. The bacteria can invade and persist in both nonprofessional and professional phagocytic cells making the infection persistent through one lactation to the next [4-7]. The predominant capsular types in S. aureus are CP5 and CP8 and the prevalence of non-typeable (NT) S. aureus in human clinical isolates are less than 25\% [3]. In contrast, S. aureus isolates from bovine mastitis cases are mostly non-typeable up to $86 \%$ [8], only $14-40 \%$ of the strains producing CP5 or CP8 [4-7]. While investigating the prevalence of $S$. aureus $\mathrm{CP}$ types associated with bovine mastitis cases in Australia and India, around $30 \%$ and $40 \%$ of the isolates were detected to be non-typeable, respectively [9]. NT S. aureus strains are associated with chronicity of infection as they can invade the mammary epithelial cells in higher numbers than the encapsulated ones leading to persistence of intramammary infection for longer duration [8].

Biofilm forming ability of $S$. aureus is an important virulent factor associated with bovine mastitis $[10,11]$. After entering the mammary gland, $S$. aureus adheres into the mammary epithelial lining and start forming biofilm [12]. Biofilm helps the pathogen to resist phagocytosis and antimicrobial agents by aggregation of colonies and formation of exopolysaccharide matrix leading to persistent infections of the mammary gland [13] and antibiotic treatment failure [14-16]. Bacteria in biofilm are 10-1000 times more resistant to antimicrobial agents than its planktonic form [17]. In addition, there is evidence of stimulation of biofilm formation by certain antibiotics such as tetracycline and erythromycin if used in sub inhibitory concentrations [18-23]. In addition, sub-inhibitory concentration of antibiotics is one of the major reasons of mastitis treatment failure leading to relapses and reinfections of mastitis in dairy cows [24]. The development of biofilm occurs in three steps including initial adherence, subsequent maturation and final detachment or dispersal and these steps are physiologically different from one another. The wide variety of extracellular virulence antigens of $S$. aureus have been reported to be associated with biofilm formation including PNAG (poly-N-acetylglucosamine), surface associated MSCRAMMS (microbial surface components recognizing adhesive matrix molecules) such as FnBPA, FnBPB, clfA, clfB, cna, Bap, Protein A, SasG, phenol soluble modulins and BBP, extracellular DNA and toxins (hla and hlb) [18-23]. However, the widely described method of development of biofilm is the PIA (polysaccharide intercellular adhesion)/PNAG production which is synthesized by icaADBC operon of $S$. aureus $[25,26]$. S. aureus in biofilm is entirely a different entity compared to its planktonic form regarding phenotypic characteristics [27], antibiotic resistance pattern [12] and development of innate immune response [28]. While studying the immunogenicity of $S$. aureus in biofilm versus planktonic cultures in an experimental mouse mastitis model, we demonstrated that $S$. aureus in biofilm induced stronger and differential immune responses from its planktonic counterpart [29]. In a pilot study using a non-invasive mouse mastitis model, we noted severe mammary tissue damage with significantly higher levels of TNF- $\alpha$ in mice infected with strong biofilm producing CP8 positive S. aureus compared to weak biofilm former CP8 positive S. aureus [30].

Considering the predominance of NT S. aureus strains in bovine mastitis etiology, the ability of $S$. aureus to produce biofilm in the mammary gland and to induce distinct immune responses than its planktonic form, it is important to understand the extent of mammary tissue damage associated with intramammary infection with strong versus weak biofilm forming NT S. aureus. Few earlier studies focused on the virulence potential of $S$. aureus as slime versus non-slime producers [31], coagulase positive versus negative strains [32], 
and small colony variants of S. aureus [33]. However, there is paucity of knowledge about the impact of strength of in vitro biofilm formation by clinical NT S. aureus on the mammary gland pathology. To the best of our knowledge, no studies have been conducted to investigate the association between strength of biofilm formation by NT S. aureus and the mammary tissue damage due to production of inflammatory cytokines, the central mediators of inflammatory response during mastitis [34]. This study was undertaken to investigate the impact of biofilm formation by clinical NT S. aureus on cytokine production and mammary tissue damage. In our previous studies, it was discovered that damage caused to the mammary gland by infection with encapsulated S. aureus was associated with the strength of biofilm formation with an increase in TNF- $\alpha$ level [30]. The current study hypothesised that mice infected with NT S. aureus with strong biofilm forming potential will develop severe mammary tissue damage compared to the NT S. aureus with weak biofilm forming potential. The aim of this experiment, therefore, was to investigate association between PIA-dependent biofilm production by clinical NT S. aureus and mammary gland pathology by using a mouse mastitis model.

The use of large animal models including cow, goat, and sheep, to study bovine mastitis has its associated problems such as cost and management, even using minimal number of animals. Besides, only limited number of hypotheses can be studied in large animals [35]. Mouse is still considered a suitable animal model for bovine mastitis research due to cost effectiveness, minimum management and similarity between mouse and cow's mammary glands in respect to neutrophil infiltration and tissue damage [35]. Both the species have two pairs of anatomically and functionally independent mammary glands in inguinal region [36]. In addition to these two pairs, mouse has three additional pairs of mammary glands in the thoracic region which can be used to study additional parameters in mastitis research [36].

\section{Materials and Methods}

\subsection{S. aureus Phenotypes}

Two NT S. aureus strains isolated from mastitis cases of cows, with strong or weak biofilm forming potential, were used in this investigation (Table 1). Both the strains were selected from a collection of 154 strains from cows in dairy farms in Victoria and Queensland, Australia suffering from clinical and subclinical mastitis. The phenotypic characteristics that were used to select these 2 strains were capsule formation, biofilm forming potential, presence or absence of biofilm-associated genes including $i c a, s p a, b b p$, $h l a$, and $h l b$. The reference $S$. aureus strains used in this study were strain M (CP1), Smith diffuse strain (CP2), USA 400 MW2 (CP8), Strain Newman and USA 100 NRS 648 (CP5), $\mathrm{CP}$-negative isolates (USA 300 LAC and USA 300 NRS 648) and a strong biofilm-forming strain ATCC 29,213 as a positive control.

Table 1. Phenotypic characteristics of Staphylococcus aureus strains used in the study.

\begin{tabular}{|c|c|c|c|c|c|c|c|c|}
\hline S1 No & $\begin{array}{l}\text { S. aureus } \\
\text { Strain }\end{array}$ & $\begin{array}{c}\text { Capsular } \\
\text { Polysaccharide } \\
\text { Type }\end{array}$ & $\begin{array}{c}\text { Biofilm } \\
\text { Formation } \\
\text { (TCP */CRA ** } \\
\text { Method) }\end{array}$ & $\begin{array}{r}\text { Preser } \\
\mathrm{G} \\
i \\
i\end{array}$ & $\begin{array}{l}\text { of } i c a \\
\text { es } \\
\text { i }\end{array}$ & $\begin{array}{l}\text { spa } \\
\text { Gene }\end{array}$ & $\begin{array}{c}b b p \\
\text { Gene }\end{array}$ & $\begin{array}{l}\text { Presence of Alpha } \\
\text { (hla) and Beta }(h l b) \\
\text { Toxin Genes }\end{array}$ \\
\hline 1 & S. aureus 83 & Non-capsulated & $\begin{array}{l}\text { Strong biofilm } \\
\left(\mathrm{OD}^{* * *} 0.775\right)\end{array}$ & +ve & + ve & +ve & +ve & hla, hlb \\
\hline 2 & S. aureus 87 & Non-capsulated & $\begin{array}{l}\text { Weak biofilm } \\
\text { (OD 0.367) }\end{array}$ & - ve & $-\mathrm{ve}$ & - ve & - ve & hla, hlb \\
\hline
\end{tabular}

* TCP: tissue culture plate; ${ }^{* *}$ CRA: Congo red agar; ${ }^{* * *}$ OD: optical density.

\subsection{Capsular Typing of S. aureus}

Capsular typing of the S. aureus strains used in this investigation was carried out using molecular as well as serological methods as described elsewhere [9]. Briefly, Extraction of DNA from the 2 strains of $S$. aureus was accomplished using the extraction kit (MO 
BIO laboratories, Inc, Carlsbad, CA, USA). The PCR cycling parameters for cap1, cap5 and cap 8 have been described previously [16]. For serotyping CP 1, 2, 5, and 8 specific antisera were produced in Quackenbush Swiss line 5 mice after gaining approval from the Animal Ethics Committee of Curtin University (Approval number: AEC_2011_65). The preparation of the vaccines and production of $\mathrm{CP}$-specific sera were carried out according to the methods previously described [9]. A slide agglutination test was performed to determine the serotype of the 4 strains of $S$. aureus. Each strain was grown on Mueller Hinton (MH) agar plates at $37^{\circ} \mathrm{C}$ overnight and a single colony was picked and suspended in a drop of $0.9 \%$ normal saline on a clean glass slide. A drop of serum was added to the suspension and checked for formation of agglutination within $20 \mathrm{~s}$. The strains, which did not show agglutination against $\mathrm{CP} 1,2,5$ and 8-specific antisera were considered as non-typeable (Table 1).

\subsection{Determination of Biofilm Forming Potential of S. aureus}

Biofilm forming potential of the two NT S. aureus strains were determined by Congo red agar (CRA) method and Tissue Culture plate (TCP) method as described previously [16] (Table 1).

\subsection{Detection of PIA-Dependent Biofilm Production Related Genes of S. aureus}

The ica typing of the S. aureus isolates were accomplished by using conventional PCR described elsewhere [37] (Table 1).

\subsection{Detection of Virulence Genes of S. aureus}

Conventional PCR was carried out to detect biofilm related MSCRAMM and toxin genes of the two NT $S$. aureus strains. The primers, Tm, for all the MSCRAMM-encoding (cna, clfA, clfB, spa, fnbp A, fnbp B, bbp , isd A, isdB, sdrD, sdrE and bap) and toxin genes (hla, $h l b$, eta, etb, pol and tsst-1) of the $S$. aureus strains used in this study have been described elsewhere [38] (Table 1).

\subsection{Infection of Mammary Gland Using NT S. aureus Strains}

2.6.1. Animal Ethics Approval

All animal work described in this investigation was approved by the Animal Ethics Committee of Curtin University (Approval number: AEC_2012_14) prior to commencement of the experiment. The mice were used for the study ensuring compliance with the Western Australian Animal Welfare Act 2002.

\subsubsection{Preparation of Bacterial Inocula}

The two NT S. aureus strains, S. aureus 83 and 87 were harvested on MH agar plates at $37^{\circ} \mathrm{C}$ for $18 \mathrm{~h}$. The colonies were washed from the plates using $20 \mathrm{~mL}$ of isotonic saline and suspended in isotonic saline to give a final viable bacterial count of $4 \times 10^{11} \mathrm{~mL}^{-1}$ [39].

\subsubsection{Mice}

A total of 12 Balb/c first-pregnancy mice, in three groups (such as strain 83, strain 87, control groups) comprising 4 mice in each group were used for the experiment. The 515 days old pups were removed from the lactating mice approximately $1 \mathrm{~h}$ prior to the experiment and euthanized.

\subsubsection{Method of Infection of the Mammary Gland}

Infection of mammary glands using S. aureus 83 and 87 was carried out using a slightly modified procedure (Protocol S1) [40] described elsewhere [30]. Briefly, mice were anaesthetised using $100 \mathrm{mg} \mathrm{kg}^{-1}$ ketamine and $10 \mathrm{mg} \mathrm{kg}^{-1}$ xylazine administered by the intraperitoneal route and surrounding area of the fifth pair of mammary glands (L5 and R5) was disinfected with $70 \%$ ethanol. The duct orifice of the teat was located using a binocular dissecting microscope and $0.05 \mathrm{~mL}$ of bacterial suspension equivalent to $2 \times 10^{10} \mathrm{CFU}$ 
(Colony Forming Unit) S. aureus was injected using a blunt smooth 31-gauge hypodermic needle to a depth of not more than $4 \mathrm{~mm}$. The mammary glands were harvested for $48 \mathrm{~h}$ and the mice were observed at six-hour intervals to assess development of macroscopic clinical signs of infection. The control group of mice was injected with normal saline following the same procedure.

\subsubsection{Post Inoculation Examination}

Macroscopic Examination

The mice were monitored at an interval of $6 \mathrm{~h}$ for the clinical symptoms or any mortality. The $48 \mathrm{~h}$ post-infection was chosen for euthanasia as per the experimental mastitis model standerdised by Anderson and Chandler to study histological and bacteriological changes caused by S. aureus [39]. However, in our study none of the mice survived until $48 \mathrm{~h}$. The level of clinical signs was graded as 0 (no macroscopic changes) ++ (low) grade, ++ (medium grade) and +++ (severe grade) based on the observed clinical features including redness, swelling, and discolouration of mammary gland, exudate, morbidity, and mortality (Table S1).

\section{Bacteriological Procedure \\ Mammary Gland}

After $48 \mathrm{~h}$ of infection, L5 mammary glands from both control and test mice were collected aseptically and processed for bacteriological load study [39]. The mammary glands were ground individually in sterile Griffith's tubes containing $2 \mathrm{~mL}$ of sterile normal saline. The homogenates from the mammary glands were subjected to serial tenfold dilutions and inoculated on Baird Parker (BP) agar plates (Pathwest, Laboratory Medicine, WA) by the spread plate method and incubated at $37^{\circ} \mathrm{C}$ for $48 \mathrm{~h}$, followed by determination of colony counts of $S$. aureus per mammary gland.

Blood, Liver, Lung, and Spleen

Blood samples obtained by cardiac puncture and organs including liver, lung and spleen homogenates were inoculated on BP agar plates and incubated at $37^{\circ} \mathrm{C}$ for $48 \mathrm{~h}$.

Histological and Cytological Procedure

Mammary Gland

After $48 \mathrm{~h}$ of infection, R5 mammary glands were collected aseptically for histological examination [39]. Prior to embedding in paraffin wax, glands were fixed using $10 \%$ neutral buffered formalin for $24 \mathrm{~h}$ and processed on an automatic tissue processor. Sections were cut at $4 \mu \mathrm{m}$ thickness at three levels and stained by the Haematoxylin and Eosin stain [41]. An additional section was stained for bacteria using the Gram Twort Method [42].

Blood

Blood smears were prepared following standard procedure and stained by the Diff Quik method [43].

\section{Grading of Histological Changes Observed in Mammary Glands}

The histopathological changes observed in mammary glands of mice, infected with S. aureus 83 and 87 were graded as follows:

Level 0: No reaction.

Level 1: Organisms identified with minimal inflammatory response in mammary tissue.

Level 2: Moderate inflammation in peri-mammary and intramammary tissue with intra luminal organisms observed.

Level 3: Marked inflammatory cell infiltration into mammary tissue in the presence of organisms with evidence of tissue degeneration including necrosis. 


\subsubsection{Quantification of Inflammatory Cytokines}

BD cytometric Bead Array (CBA) Mouse/Rat soluble protein Master Buffer Kit (BD Biosciences), USA was used to quantify inflammatory cytokines, IL-1 $\beta$, IL-6, IL-10, IL-12, IL-17A, IFN- $\gamma$ and TNF- $\alpha$ in serum samples of mice. Standard protocol provided with the kit was used to prepare Mouse/Rat soluble protein flex set standards, capture beads and detection reagents. Briefly, $50 \mu \mathrm{L}$ of Mouse/Rat soluble protein flex set standard dilutions ranging from 1:2 to 1:256 and one negative control containing only assay diluent was prepared. To $10 \mu \mathrm{L}$ of each unknown serum sample, $10 \mu \mathrm{L}$ of each capture bead and mixed PE (phycoerythrin) detection reagent was added. After adding capture beads and $\mathrm{PE}$ detection reagent tubes were incubated at $4{ }^{\circ} \mathrm{C}$ for $1 \mathrm{~h}$ each after in dark. Immediately after incubation, $200 \mu \mathrm{L}$ of wash buffer was added to each tube and centrifuged at $200 \times g$ for $5 \mathrm{~min}$. The supernatant was aspirated, discarded and the remaining pellet was reconstituted using $200 \mu \mathrm{L}$ of wash buffer. This reconstituted pellet was used for acquiring on an Attune Acoustic Focusing Flow Cytometer (Thermofisher Scientific, Waltham, MA, USA). Samples were analysed using the FlowJo software.

\subsubsection{Statistical Analysis}

Statistical analysis was carried out using Student's $t$-test to compare total viable counts of $S$. aureus recovered from mammary glands injected with non-typeable strong biofilm forming $S$. aureus and weak biofilm forming $S$. aureus. The Student's $t$-test was also performed to compare the IL-1 $\beta$, IL-6, IL10, IL-12, IL-17, TNF- $\alpha$ and IFN- $\gamma$ levels between groups of mice injected with $S$. aureus phenotypes. Statistical significance was set at $p<0.05$.

\section{Results}

\subsection{Detection of Capsular Types of S. aureus}

Both S. aureus 83 and 87 were found to be non-capsulated as these strains carried none of the three loci (cap5, cap 8 or cap 1 ) and were not agglutinated by any of the CP-specific sera (CP 1, CP 2, CP 5 and $C P$ 8) subjected to slide agglutination test.

\subsection{Determination of Biofilm Forming Potential of S. aureus Isolates}

\subsubsection{CRA and TCP Method}

In both CRA and TCP methods, S. aureus strain 83 (OD value 0.775 ) was detected to be strong biofilm former in vitro whereas $S$. aureus strain 87 (OD value 0.367 ) was a weak biofilm former in vitro.

\subsection{2. ica Typing of S. aureus Isolates}

S. aureus strain 83 confirmed PIA dependant biofilm formations by harbouring the $i c a \mathrm{~A}$ and ica $\mathrm{D}$ genes whereas these genes were not detectable in S. aureus strain 87 .

\subsection{Detection of Different MSCRAMM-Encoding Genes of S. aureus Using Conventional PCR}

Both $S$. aureus strains harboured genes encoding alpha and beta toxin. S. aureus 83 carried $c l f A, c l f B, s p a, b b p$, isd $A$, is $d B, s d r D$ and $s d r E$ MSCRAMM genes. S. aureus 87 was found to carry $c l f A, c l f B$, isd $A$, isdB, $s d r D$ and $s d r E$ genes (Table 1).

\subsection{Macroscopic Examination of Mammary Glands for Clinical Symptoms}

The control group of mice injected with normal saline did not show any clinical symptoms and the mammary glands appeared normal. Both the test groups of mice infected with S. aureus 83 and 87 strains showed medium grades of clinical symptoms. However, mice injected with S. aureus 83 died $24 \mathrm{~h}$ of post inoculation and the group injected with S. aureus 87 died $30 \mathrm{~h}$ post inoculation (Table 2). 
Table 2. Clinical signs observed in different groups of mice post-infection (observations up to $30 \mathrm{~h}$ post inoculation).

\begin{tabular}{|c|c|c|c|c|c|c|c|c|c|c|c|c|}
\hline \multirow{2}{*}{$\begin{array}{l}\text { Time Post } \\
\text { Inoculation }\end{array}$} & \multicolumn{4}{|c|}{ S. aureus 83} & \multicolumn{4}{|c|}{ S. aureus 87} & \multicolumn{4}{|c|}{ Normal Saline (Control) } \\
\hline & $P^{* 1}$ & P2 & P3 & P4 & P1 & P2 & P3 & P4 & P1 & P2 & P3 & P4 \\
\hline $6 \mathrm{~h}$ & 0 & 0 & 0 & 0 & 0 & 0 & 0 & 0 & 0 & 0 & 0 & 0 \\
\hline $12 \mathrm{~h}$ & + & + & + & + & + & + & + & + & 0 & 0 & 0 & 0 \\
\hline $18 \mathrm{~h}$ & ++ & ++ & ++ & ++ & + & + & + & + & 0 & 0 & 0 & 0 \\
\hline $24 \mathrm{~h}$ & $++/ \mathrm{D}$ & $++/ \mathrm{D}$ & $++/ \mathrm{D}$ & $++/ \mathrm{D}$ & ++ & ++ & ++ & + & 0 & 0 & 0 & 0 \\
\hline $30 \mathrm{~h}$ & - & - & - & - & $++/ D$ & $++/ D$ & $++/ D$ & $++/ D$ & 0 & 0 & 0 & 0 \\
\hline
\end{tabular}

* P: pair; fifth pair of mammary glands (L5 and R5) in each mouse; clinical features include redness, swelling, and discolouration of mammary gland, exudate, morbidity, and mortality; grade scores compare observed features to the most severe changes: 0 no macroscopic changes, + low grade, ++ medium grade, +++ severe grade.

\subsection{Bacterial Load and Histopathological Changes of Mammary Gland}

The log average number of bacteria (CFU) isolated from the mammary glands of all the 3 groups of mice including control group and the associated histopathological changes in the mammary glands are presented in Table 3. The bacterial load of mammary glands of mice infected with $S$. aureus 83 was significantly higher $(p<0.05)$ with $8.23 \pm 0.001 \mathrm{CFU}$ compared to those infected with $S$. aureus 87 which was $7.91 \pm 0.003 \mathrm{CFU}$.

Table 3. Total viable counts of NT S. aureus recovered from mammary glands after death of mice and histopathology of mammary glands.

\begin{tabular}{cccccc}
\hline Group & $\begin{array}{c}\text { Total Number of } \\
\text { Mammary Glands } \\
\text { Investigated }\end{array}$ & $\begin{array}{c}\text { Log Average Number of Bacteria } \\
\text { (CFU }{ }^{3} \text { ) Recovered from } \\
\text { Mammary Glands } \pm \text { SE }\end{array}$ & \multicolumn{3}{c}{ Histopathology Grade } \\
M. & 4 & $8.23 \pm 0.001 *$ & M2 & M3 \\
\hline S. aureus 83 & 4 & $7.91 \pm 0.003$ & 1 & 1 & 1 \\
S. aureus 87 & 4 & 0 & 0 & 1 & 1 \\
Control (NS $^{2}$ ) & 4 & 0 & 0 \\
\hline
\end{tabular}

${ }^{*} p<0.05$, the comparison of results of bacterial load was undertaken between S. aureus 83 and S. aureus 87 groups; ${ }^{1} \mathrm{~L} 5$ and R5 mammary glands were used for bacteriological and histological procedures, respectively; ${ }^{2} \mathrm{NS}=$ normal saline; ${ }^{3} \mathrm{CFU}=$ colony forming unit:

${ }^{4} \mathrm{M}=$ mammary gland.

\subsubsection{Bacteriology of Blood and Histopathology of Liver, Lung, and Spleen}

The culture of blood and organs (liver, lung and spleen) in BP agar plates was negative for $S$. aureus indicating no evidence of systemic infection. There was no evidence of inflammation in tissue sections of lung, liver and spleen from any of the mice.

3.5.2. Histopathology of Mammary Glands Post-infection with Biofilm Forming S. aureus

No evidence of inflammatory response was recorded in mammary tissue of control mice which were inoculated with sterile normal saline. The mammary tissue of all the mice infected with S. aureus 83 and 87 demonstrated identical Level 1 inflammation.

\subsection{Quantification of Inflammatory Cytokines in Serum}

Quantification study of inflammatory cytokines, IL-1 $\beta$, IL-6, TNF- $\alpha$ and other cytokines including IL-10, IL-12, IL-17A and IFN- $\gamma$ showed that the levels of IL-1 $\beta$, IL-6, IL-12, IL-17 and IFN- $\gamma$ were significantly higher $(p<0.05)$ in the sera of mice inoculated with non-typeable strong biofilm forming S. aureus 83 than those inoculated with weak biofilm forming non typeable S. aureus 87 (Table 4). 
Table 4. Detection of levels of different cytokine biomarkers in sera samples of mice before death.

\begin{tabular}{|c|c|c|c|c|c|c|c|c|}
\hline Group & $\begin{array}{l}\text { S. aureus } \\
\text { Phenotype }\end{array}$ & $\begin{array}{c}\mathrm{IL}-1 \beta \\
\mathrm{Pg} / \mathrm{mL} \pm \mathrm{SE}\end{array}$ & $\begin{array}{c}\text { IL-6 } \\
\mathrm{Pg} / \mathrm{mL} \pm \mathrm{SE}\end{array}$ & $\begin{array}{c}\mathrm{IL}-10 \\
\mathrm{Pg} / \mathrm{mL} \pm \mathrm{SE}\end{array}$ & $\begin{array}{c}\mathrm{IL}-12 \\
\mathrm{Pg} / \mathrm{mL} \pm \mathrm{SE}\end{array}$ & $\begin{array}{c}\text { IL-17A } \\
\mathrm{Pg} / \mathrm{mL} \pm \mathrm{SE}\end{array}$ & $\begin{array}{c}\text { IFN- } \gamma \\
\mathrm{Pg} / \mathrm{mL} \pm \mathrm{SE}\end{array}$ & $\begin{array}{c}\text { TNF- } \alpha \\
\mathrm{Pg} / \mathrm{mL} \pm \mathrm{SE}\end{array}$ \\
\hline 1 & S. aureus 83 & $321.7^{*} \pm 23$ & $15479.9 * \pm 532$ & $66.8 * \pm 0.96$ & $3.0 * \pm 0.42$ & $28.6 * \pm 1.79$ & $59.5 * \pm 1.78$ & $163.3 \pm 4.5$ \\
\hline 2 & S. aureus 87 & $27.7 \pm 41$ & $529 \pm 109$ & $12.86 \pm 0.69$ & $1.43 \pm 0.35$ & $18.20 \pm 0.5$ & $12.70 \pm 1.50$ & $174.9 \pm 21$ \\
\hline & Control (NS) & 0 & 0 & 0 & & & 0 & \\
\hline
\end{tabular}

${ }^{*} p<0.05$, the comparison of results of inflammatory cytokines was undertaken between S. aureus 83 and S. aureus 87 groups.

\section{Discussion}

Globally, S. aureus remains one of the predominant causes of clinical and subclinical mastitis in dairy ruminants. Non-typeable strains of $S$. aureus can survive in the mammary gland for longer duration than the encapsulated strains $[2,8]$. Higher degree of inflammation appeared to have been induced by encapsulated S. aureus than the non-typeable S. aureus strains, which leads to quick clearance of these cells by the host immune system. The non-typeable cells are quickly internalized by the mammary epithelial cells due to absence of capsule and thus they are protected from the action of phagocytic cells [8] and allows bacteria to persist leading to chronic infection [44]. Biofilm producing S. aureus can attach more effectively to the epithelial lining of mammary glands to develop intramammary infection [31]. In fact, S. aureus isolated from mammary glands are more likely to form biofilm than S. aureus isolated from external sources including milking machines [45]. Bacteria growing in biofilm demonstrate increased resistance to antimicrobial therapy [14] due to delayed penetration of antimicrobial agents crossing the barrier of slimy biofilm matrix, modification in the growth rate of pathogens residing in biofilm and certain physiological and genotypic changes in pathogen residing in biofilm [46]. Furthermore, the ability of the macrophages to invade into biofilm is limited and the pathogen in biofilm is able to polarise the macrophages from proinflammatory microbicidal M1 phenotype to an M2 phenotype which exert anti-inflammatory properties and restrict phagocytosis $[28,47]$. To make the situation worse, in a biofilm environment, S. aureus initiate a favourable interaction with the Myeloid derived suppressor cells (MDSCs) which exert immunosuppressive properties [48] and this phenomenon is partly aggravated by cytokines such as IL10 [49] and IL12 [50]. As the NT S. aureus can remain longer in the mammary epithelial cells well protected from host phagocytosis and additionally the biofilm formation is one of the important survival strategies of the pathogen [51] in intramammary infection, it is important to understand the magnitude of mammary tissue damage post infection by NT S. aureus with different strength of biofilm forming potential for future therapeutic interventions.

In the current study, both the NT strains of S. aureus with different strength of biofilm formation produced identical clinical symptoms and mammary tissue damage. Both the strains produced moderate level of clinical symptoms of mastitis and level 1 histopathological lesion in the mammary gland. However, the bacterial load in the mammary glands of mice injected with the non-typeable $S$. aureus 83 strain with strong biofilm forming ability was significantly higher $(p \leq 0.05)$ than the weak biofilm forming $S$. aureus 87 . The period of observation in the study was $48 \mathrm{~h}$. Both the test groups of mice died before $48 \mathrm{~h}$. The mice injected with S. aureus 83 (strong biofilm former) survived only $24 \mathrm{~h}$ followed by the mice injected with S. aureus 87 (weak biofilm former). Mice in the latter died at $30 \mathrm{~h}$ post inoculation. The analysis of sera samples collected from mice immediately before death showed higher levels of IL-1 $\beta$, IL-6, IL-10, IL-17A, IFN- $\gamma$ and TNF- $\alpha$ (Table 4). In one study, it was suggested that quick internalization of non-typeable $S$. aureus cells by the mammary epithelial cells may have prevented the clearance of $S$. aureus from the mammary gland providing scope for production of high levels of cytokines of different types [52]. The highly elevated level of various cytokines can lead to cytokine storm, a fatal immune response which may result in sudden death $[53,54]$. It has been demonstrated that patients who died due to cytokine storm had higher levels of anti-inflammatory cytokine, IL-10 and pro inflammatory cytokines, IL-1 $\beta$, IL-6 and TNF- $\alpha$ in serum samples [55]. In the present study, between both the groups of test mice, the mice injected with $S$. aureus 83 produced 
significantly higher levels of IL-1 $\beta$, IL-6, IL-12, IL-17 and IFN- $\gamma(p<0.05)$ than the mice injected with $S$. aureus 87 . The level of IL-6 in sera samples of mice injected with $S$. aureus 83 was extremely high $(15479.9 \pm 532 \mathrm{Pg} / \mathrm{mL})$ which could have been responsible for the death of the mice within mere $24 \mathrm{~h}$ post inoculation. In addition, IL-12 is a cytokine with both pro and anti-inflammatory effects, can assist in the recruitment of MSDCs. IL-10, an anti-inflammatory cytokine mainly produced by the MSDCs during S. aureus biofilm infection is capable of promoting the growth of biofilm [49]. In the current study, IL-10, IL-12 and MSDCs may be the contributing factors for the development of anti-inflammatory environment in the mammary gland resulting only Grade 1 mammary tissue damage. However, this warrants further investigation.

The role of biofilm in complication of bovine mastitis has been established previously $[30,46,56]$. In this study, the only phenotypic difference between both the strains was the biofilm forming ability. Though not conclusively, it can be suggested that biofilm forming ability of non-typeable $S$. aureus may play role in the virulence of $S$. aureus as increased higher levels of PIA/PNAG-associated biofilm could be helpful in dispersion of biofilm facilitated by bacterial cell to cell interaction in the mammary gland [57] leading to higher colonisation of the pathogen in mammary tissue [31] and possibly systemic dissemination of infection [56]. This might have resulted in higher bacterial load and significantly higher levels of cytokines in mice infected with strong biofilm producing $S$. aureus which might have contributed to the mortality of the mice. In the mammary glands, inflammation has been associated with neutrophil chemo-attractants and the cytokines (IL-1 $\beta$, IL-6, TNF- $\alpha$ and IL8) $[58,59]$. Local induction of cytokines including IL-1 $\beta$ and IL- 6 post infection of the mouse mammary gland with $S$. aureus was reported by Breyne and co-workers [32]. IL-6 in quarter milk has been proven as a prediction marker of bovine mastitis [60]. In the current study, the extraordinarily high amount of IL-6 in sera samples of mice infected with biofilm forming NT S. aureus suggests an important role of IL-6 in virulence of strong biofilm forming $S$. aureus in mouse mastitis model. It will be interesting to investigate the neutralisation effect of IL-6 by anti-IL-6R antibody in preventing mortality in mice in the future investigations.

Due to non-availability of commercial mutant NT S. aureus strains of different biofilm forming potential, we have emphasized on using clinical isolates and included selected biofilm related phenotypic characteristics to be compared in the selected two S. aureus strains used in this study. This is one of the limitations of our study. Further investigation will be important to compare the virulence and pathogenicity of mutant $S$. aureus strains that are genotypically and phenotypically similar but with different biofilm forming abilities. Additionally, the expression of S. aureus biofilm in vitro may not correlate with the expression that occurs in vivo in the mammary gland. The future research will focus on comparing the in vitro attachment potential of NT S. aureus strains (used in this study) to bovine mammary epithelial cells (MAC-T) to in vivo response in either a mouse mastitis model or in dairy cows. It will be interesting to replicate this study using S. aureus with different biofilm forming potential from different species to understand if there are any species-specific differences to the host response.

The potential information generated from this study will contribute new knowledge in mastitis pathology associated with NT S. aureus and may aid in future research to strategize different treatment options with advanced pharmacological interventions to reduce tissue damage aiming to control mastitis.

\section{Conclusions}

From this study it was concluded that phenotypic PIA-dependent biofilm production by clinical non-typeable $S$. aureus is not associated with the intensity of inflammation in mammary gland. Clinical non-typeable $S$. aureus strains isolated from bovine mastitis cases developed identical moderate clinical symptoms, Grade- 1 mammary tissue damage and generated minimal inflammatory infiltrates in the mammary tissue when tested in a mouse mastitis model. 
Supplementary Materials: The following Supplementary Materials are being published alongside the article. The following are available online at https:/ / www.mdpi.com/article/10.3390/ani11113 047/s1, Protocol S1: Method of infection the mammary gland; Table S1: Grading of clinical signs.

Author Contributions: Conceptualization, J.G.-T. and T.M.; methodology, J.G.-T. and D.D.; formal analysis, J.G.-T. and H.K.T.; investigation, J.G.-T. and D.D.; resources, T.M.; data curation, J.G.-T., G.S. and H.K.T.; writing—original draft preparation, J.G.-T.; writing—review and editing, T.M., J.W.A., G.S. and H.K.T.; visualization, J.G.-T. and T.M. supervision, T.M.; project administration, T.M.; funding acquisition, T.M. All authors have read and agreed to the published version of the manuscript.

Funding: This research was funded by the Australia India Strategic Research Fund [BF040038] from the Department of Innovation, Industry, Science and Research, Commonwealth Government of Australia.

Institutional Review Board Statement: All animal work described in this study was approved by the Animal Ethics Committee of Curtin University (Approval number: AEC_2012_14) prior to commencement of the experiment.

Informed Consent Statement: The study was conducted according to the guidelines of Western Australian Animal Welfare Act 2002 and approved by the Animal Ethics Committee of CURTIN UNIVERSITY (Approval number: AEC_2012_14).

Data Availability Statement: All the data generated from this research are available upon reasonable request.

Acknowledgments: Authors are thankful to Associate Professor Vincent Williams and Karl Fairhurst, senior technician, School of Biomedical Sciences, Curtin University for assisting with histopathology and Tammy De Jong, Life Sciences Research Facility, Office of Research and Development, building 300, Curtin University, Perth for helping us to look after the experimental animals during the study. The authors acknowledge the provision of research facilities and the scientific and technical assistance of the staff of CHIRI Biosciences Research Precinct core facility, Curtin University.

Conflicts of Interest: The authors declare no conflict of interest. The funders had no role in the design of the study; in the collection, analyses, or interpretation of data; in the writing of the manuscript, or in the decision to publish the results.

\section{References}

1. Bardiau, M.; Detilleux, J.; Farnir, F.; Mainil, J.G.; Ote, I. Associations between properties linked with persistence in a collection of Staphylococcus aureus isolates from bovine mastitis. Vet. Microbiol. 2014, 169, 74-79. [CrossRef] [PubMed]

2. Zaatout, N.; Ayachi, A.; Kecha, M. Staphylococcus aureus persistence properties associated with bovine mastitis and alternative therapeutic modalities. J. Appl. Microbiol. 2020, 129, 1102-1119. [CrossRef] [PubMed]

3. O'Riordan, K.; Lee, J.C. Staphylococcus aureus capsular polysaccharides. Clin. Microbiol. Rev. 2004, 17, 218-234. [CrossRef] [PubMed]

4. Sompolinsky, D.; Samra, Z.; Karakawa, W.; Vann, W.; Schneerson, R.; Malik, Z. Encapsulation and capsular types in isolates of Staphylococcus aureus from different sources and relationship to phage types. J. Clin. Microbiol. 1985, 22, 828-834. [CrossRef] [PubMed]

5. Poutrel, B.; Boutonnier, A.; Sutra, L.; Fournier, J. Prevalence of capsular polysaccharide types 5 and 8 among Staphylococcus aureus isolates from cow, goat, and ewe milk. J. Clin. Microbiol. 1988, 26, 38-40. [CrossRef]

6. Han, H.; Pak, S.I.; Guidry, A. Prevalence of capsular polysaccharide (CP) types of Staphylococcus aureus isolated from bovine mastitic milk and protection of S. aureus infection in mice with CP vaccine. J. Vet. Med. Sci. 2000, 62, 1331-1333. [CrossRef]

7. Sordelli, D.O.; Buzzola, F.R.; Gomez, M.I.; Steele-Moore, L.; Berg, D.; Gentilini, E.; Catalano, M.; Reitz, A.J.; Tollersrud, T.; Denamiel, G.; et al. Capsule expression by bovine isolates of Staphylococcus aureus from Argentina: Genetic and epidemiologic analyses. J. Clin. Microbiol 2000, 38, 846-850. [CrossRef]

8. Tuchscherr, L.P.; Buzzola, F.R.; Alvarez, L.P.; Caccuri, R.L.; Lee, J.C.; Sordelli, D.O. Capsule-negative Staphylococcus aureus induces chronic experimental mastitis in mice. Infect. Immun. 2005, 73, 7932-7937. [CrossRef]

9. Gogoi-Tiwari, J.; Babra Waryah, C.; Sunagar, R.; Veeresh, H.B.; Nuthanalakshmi, V.; Preethirani, P.L.; Sharada, R.; Isloor, S.; Bhat, A.; Al-Salami, H.; et al. Typing of Staphylococcus aureus isolated from bovine mastitis cases in Australia and India. Aust Vet. J. 2015, 93, 278-282. [CrossRef]

10. Hensen, S.; Pavičić, M.; Lohuis, J.; Poutrel, B. Use of bovine primary mammary epithelial cells for the comparison of adherence and invasion ability of Staphylococcus aureus strains. J. Dairy Sci. 2000, 83, 418-429. [CrossRef]

11. Aguilar, B.; Amorena, B.; Iturralde, M.a. Effect of slime on adherence of Staphylococcus aureus isolated from bovine and ovine mastitis. Vet. Microbiol. 2001, 78, 183-191. [CrossRef] 
12. Cucarella, C.; Tormo, M.A.; Ubeda, C.; Trotonda, M.P.; Monzón, M.; Peris, C.; Amorena, B.; Lasa, I.; Penadés, J.R. Role of biofilm-associated protein bap in the pathogenesis of bovine Staphylococcus aureus. Infect. Immun. 2004, 72, 2177-2185. [CrossRef]

13. Fabres-Klein, M.H.; Santos, M.J.C.; Klein, R.C.; de Souza, G.N.; Ribon, A.d.O.B. An association between milk and slime increases biofilm production by bovine Staphylococcus aureus. BMC Vet. Res. 2015, 11, 1-8. [CrossRef] [PubMed]

14. Olson, M.E.; Ceri, H.; Morck, D.W.; Buret, A.G.; Read, R.R. Biofilm bacteria: Formation and comparative susceptibility to antibiotics. Can. J. Vet. Res. 2002, 66, 86.

15. Conley, J.; Olson, M.E.; Cook, L.S.; Ceri, H.; Phan, V.; Davies, H.D. Biofilm formation by group A streptococci: Is there a relationship with treatment failure? J. Clin. Microbiol. 2003, 41, 4043-4048. [CrossRef]

16. Babra, C.; Tiwari, J.G.; Pier, G.; Thein, T.H.; Sunagar, R.; Sundareshan, S.; Isloor, S.; Hegde, N.R.; de Wet, S.; Deighton, M. The persistence of biofilm-associated antibiotic resistance of Staphylococcus aureus isolated from clinical bovine mastitis cases in Australia. Folia Microbiol. 2013, 58, 469-474. [CrossRef]

17. Rachid, S.; Ohlsen, K.; Witte, W.; Hacker, J.r.; Ziebuhr, W. Effect of subinhibitory antibiotic concentrations on polysaccharide intercellular adhesin expression in biofilm-forming Staphylococcus epidermidis. Antimicrob. Agents Chemother. 2000, 44, 3357-3363. [CrossRef]

18. McDevitt, D.; Francois, P.; Vaudaux, P.; Foster, T. Molecular characterization of the clumping factor (fibrinogen receptor) of Staphylococcus aureus. Mol. Microbiol. 1994, 11, 237-248. [CrossRef] [PubMed]

19. Patti, J.M.; Jonsson, H.; Guss, B.; Switalski, L.M.; Wiberg, K.; Lindberg, M.; Höök, M. Molecular characterization and expression of a gene encoding a Staphylococcus aureus collagen adhesin. J. Biol. Chem. 1992, 267, 4766-4772. [CrossRef]

20. O'Neill, E.; Pozzi, C.; Houston, P.; Humphreys, H.; Robinson, D.A.; Loughman, A.; Foster, T.J.; O'Gara, J.P. A novel Staphylococcus aureus biofilm phenotype mediated by the fibronectin-binding proteins, FnBPA and FnBPB. J. Bacteriol. 2008, 190, 3835-3850. [CrossRef]

21. Tung, H.-s.; Guss, B.; Hellman, U.; Persson, L.; Rubin, K.; Rydén, C. A bone sialoprotein-binding protein from Staphylococcus aureus: A member of the staphylococcal Sdr family. Biochem. J. 2000, 345, 611-619. [CrossRef]

22. Caiazza, N.C.; O'Toole, G.A. Alpha-toxin is required for biofilm formation by Staphylococcus aureus. J. Bacteriol. 2003, 185, 3214-3217. [CrossRef] [PubMed]

23. Abraham, N.M.; Jefferson, K.K. Staphylococcus aureus clumping factor B mediates biofilm formation in the absence of calcium. Microbiology 2012, 158, 1504. [CrossRef] [PubMed]

24. du Preez, J.H. Bovine mastitis therapy and why it fails. J. S. Afr. Vet. Assoc. 2000, 71, 201-208. [CrossRef] [PubMed]

25. Cramton, S.E.; Gerke, C.; Schnell, N.F.; Nichols, W.W.; Götz, F. The intercellular adhesion (ica) locus is present in Staphylococcus aureus and is required for biofilm formation. Infect. Immun. 1999, 67, 5427-5433. [CrossRef]

26. Mack, D.; Fischer, W.; Krokotsch, A.; Leopold, K.; Hartmann, R.; Egge, H.; Laufs, R. The intercellular adhesin involved in biofilm accumulation of Staphylococcus epidermidis is a linear beta-1,6-linked glucosaminoglycan: Purification and structural analysis. J. Bacteriol 1996, 178, 175-183. [CrossRef] [PubMed]

27. Shemesh, M.; Tam, A.; Steinberg, D. Differential gene expression profiling of Streptococcus mutans cultured under biofilm and planktonic conditions. Microbiology 2007, 153, 1307-1317. [CrossRef]

28. Thurlow, L.R.; Hanke, M.L.; Fritz, T.; Angle, A.; Aldrich, A.; Williams, S.H.; Engebretsen, I.L.; Bayles, K.W.; Horswill, A.R.; Kielian, T. Staphylococcus aureus biofilms prevent macrophage phagocytosis and attenuate inflammation in vivo. J. Immunol. 2011, 186, 6585-6596. [CrossRef]

29. Gogoi-Tiwari, J.; Williams, V.; Waryah, C.B.; Eto, K.Y.; Tau, M.; Costantino, P.; Tiwari, H.K.; Mukkur, T. Comparative studies of the immunogenicity and protective potential of biofilm vs. planktonic Staphylococcus aureus vaccine against bovine mastitis using non-invasive mouse mastitis as a model system. Biofouling 2015, 31, 543-554. [CrossRef] [PubMed]

30. Gogoi-Tiwari, J.; Williams, V.; Waryah, C.B.; Costantino, P.; Al-Salami, H.; Mathavan, S.; Wells, K.; Tiwari, H.K.; Hegde, N.; Isloor, S.; et al. Mammary Gland Pathology Subsequent to Acute Infection with Strong versus Weak Biofilm Forming Staphylococcus aureus Bovine Mastitis Isolates: A Pilot Study Using Non-Invasive Mouse Mastitis Model. PLoS ONE 2017, 12, e0170668. [CrossRef]

31. Baselga, R.; Albizu, I.; De La Cruz, M.; Del Cacho, E.; Barberan, M.; Amorena, B. Phase variation of slime production in Staphylococcus aureus: Implications in colonization and virulence. Infect. Immun. 1993, 61, 4857-4862. [CrossRef]

32. Breyne, K.; De Vliegher, S.; De Visscher, A.; Piepers, S.; Meyer, E. A pilot study using a mouse mastitis model to study differences between bovine associated coagulase-negative staphylococci. J. Dairy Sci. 2015, 98, 1090-1100. [CrossRef]

33. Sifri, C.D.; Baresch-Bernal, A.; Calderwood, S.B.; von Eiff, C. Virulence of Staphylococcus aureus small colony variants in the Caenorhabditis elegans infection model. Infect. Immun. 2006, 74, 1091-1096. [CrossRef] [PubMed]

34. Paape, M.J.; Bannerman, D.D.; Zhao, X.; Lee, J.W. The bovine neutrophil: Structure and function in blood and milk. Vet. Res. 2003, 34, 597-627.

35. Brouillette, E.; Malouin, F. The pathogenesis and control of Staphylococcus aureus-induced mastitis: Study models in the mouse. Microbes Infect. 2005, 7, 560-568. [CrossRef]

36. Notebaert, S.; Meyer, E. Mouse models to study the pathogenesis and control of bovine mastitis. A review. Vet. Q. 2006, 28, 2-13. [CrossRef] [PubMed]

37. Babra, C.; Tiwari, J.; Costantino, P.; Sunagar, R.; Isloor, S.; Hegde, N.; Mukkur, T. Human methicillin-sensitive Staphylococcus aureus biofilms: Potential associations with antibiotic resistance persistence and surface polysaccharide antigens. J. Basic Microbiol. 2014, 54, 721-728. [CrossRef] 
38. Gogoi-Tiwari, J.; Waryah, C.B.; Eto, K.Y.; Tau, M.; Wells, K.; Costantino, P.; Tiwari, H.K.; Isloor, S.; Hegde, N.; Mukkur, T. Relative distribution of virulence-associated factors among Australian bovine Staphylococcus aureus isolates: Potential relevance to development of an effective bovine mastitis vaccine. Virulence 2015, 6, 419-423. [CrossRef] [PubMed]

39. Anderson, J.C.; Chandler, R.L. Experimental Staphylococcal mastitis in the mouse. Histological, ultrastructural and bacteriological changes caused by a virulent strain of Staphylococcus aureus. J. Comp. Pathol. 1975, 85, 499-510. [CrossRef]

40. Brouillette, E.; Grondin, G.; Lefebvre, C.; Talbot, B.G.; Malouin, F. Mouse mastitis model of infection for antimicrobial compound efficacy studies against intracellular and extracellular forms of Staphylococcus aureus. Vet. Microbiol. 2004, 101, 253-262. [CrossRef]

41. Bancroft, J.D.; Gamble, M. Theory and Practice of Histological Techniques; Elsevier: Beijing, China, 2008; pp. 121-134.

42. Ollett, W.S. A method for staining both gram-positive and gram-negative bacteria in sections. J. Pathol. Bacteriol. 1947, 59, 357.

43. Skipper, R.; Destephano, D. Diff quik stain set* 64851. J. Histotechnol. 1989, 4, 303. [CrossRef]

44. Tuchscherr, L.; Löffler, B.; Buzzola, F.R.; Sordelli, D.O. Staphylococcus aureus adaptation to the host and persistence: Role of loss of capsular polysaccharide expression. Future Microbiol. 2010, 5, 1823-1832. [CrossRef]

45. Fox, L.; Zadoks, R.; Gaskins, C. Biofilm production by Staphylococcus aureus associated with intramammary infection. Vet. Microbiol. 2005, 107, 295-299. [CrossRef] [PubMed]

46. Melchior, M.; Vaarkamp, H.; Fink-Gremmels, J. Biofilms: A role in recurrent mastitis infections? Vet. J. 2006, 171, 398-407. [CrossRef]

47. Hanke, M.L.; Angle, A.; Kielian, T. MyD88-dependent signaling influences fibrosis and alternative macrophage activation during Staphylococcus aureus biofilm infection. PLoS ONE 2012, 7, e42476. [CrossRef]

48. Heim, C.E.; Vidlak, D.; Scherr, T.D.; Kozel, J.A.; Holzapfel, M.; Muirhead, D.E.; Kielian, T. Myeloid-derived suppressor cells contribute to Staphylococcus aureus orthopedic biofilm infection. J. Immunol. 2014, 192, 3778-3792. [CrossRef]

49. Heim, C.E.; Vidlak, D.; Kielian, T. Interleukin-10 production by myeloid-derived suppressor cells contributes to bacterial persistence during Staphylococcus aureus orthopedic biofilm infection. J. Leukoc. Biol. 2015, 98, 1003-1013. [CrossRef]

50. Heim, C.E.; Vidlak, D.; Scherr, T.D.; Hartman, C.W.; Garvin, K.L.; Kielian, T. IL-12 promotes myeloid-derived suppressor cell recruitment and bacterial persistence during Staphylococcus aureus orthopedic implant infection. J. Immunol. 2015, 194, 3861-3872. [CrossRef] [PubMed]

51. Hall-Stoodley, L.; Costerton, J.W.; Stoodley, P. Bacterial biofilms: From the natural environment to infectious diseases. Nat. Rev. Microbiol. 2004, 2, 95-108. [CrossRef] [PubMed]

52. Yao, L.; Bengualid, V.; Lowy, F.D.; Gibbons, J.J.; Hatcher, V.B.; Berman, J.W. Internalization of Staphylococcus aureus by endothelial cells induces cytokine gene expression. Infect. Immun. 1995, 63, 1835-1839. [CrossRef] [PubMed]

53. Osterholm, M.T. Preparing for the next pandemic. N. Engl J. Med. 2005, 352, 1839-1842. [CrossRef]

54. Fajgenbaum, D.C.; June, C.H. Cytokine Storm. N. Engl. J. Med. 2020, 383, 2255-2273. [CrossRef]

55. Tsai, M.-H.; Chang, C.-H.; Tsai, R.-K.; Hong, Y.-R.; Chuang, T.-H.; Fan, K.-T.; Peng, C.-W.; Wu, C.-Y.; Hsu, W.-L.; Wang, L.-S.; et al. Cross-Regulation of Proinflammatory Cytokines by Interleukin-10 and miR-155 in Orientia tsutsugamushi-Infected Human Macrophages Prevents Cytokine Storm. J. Investig. Dermatol. 2016, 136, 1398-1407. [CrossRef] [PubMed]

56. Gomes, F.; Saavedra, M.J.; Henriques, M. Bovine mastitis disease/pathogenicity: Evidence of the potential role of microbial biofilms. Pathog. Dis. 2016, 74, ftw006. [CrossRef] [PubMed]

57. Grønnemose, R.B.; Saederup, K.L.; Kolmos, H.J.; Hansen, S.W.K.; Asferg, C.A.; Rasmussen, K.J.; Palarasah, Y.; Andersen, T.E. A novel in vitro model for haematogenous spreading of $S$. aureus device biofilms demonstrating clumping dispersal as an advantageous dissemination mechanism. Cell. Microbiol. 2017, 19, e12785. [CrossRef]

58. Porcherie, A.; Cunha, P.; Trotereau, A.; Roussel, P.; Gilbert, F.B.; Rainard, P.; Germon, P. Repertoire of Escherichia coli agonists sensed by innate immunity receptors of the bovine udder and mammary epithelial cells. Vet. Res. 2012, 43, 1-8. [CrossRef]

59. Riollet, C.; Rainard, P.; Poutrel, B. Differential induction of complement fragment C5a and inflammatory cytokines during intramammary infections with Escherichia coli and Staphylococcus aureus. Clin. Diagn. Lab. Immunol. 2000, 7, 161-167. [CrossRef]

60. Sakemi, Y.; Tamura, Y.; Hagiwara, K. Interleukin-6 in quarter milk as a further prediction marker for bovine subclinical mastitis. J. Dairy Res. 2011, 78, 118. [CrossRef] 